\title{
FUNGSI MANAJEMEN DALAM PERENCANAAN PEMBELAJARAN
}

\section{Ishak Wanto Talibo ${ }^{1}$}

\begin{abstract}
Abstrak
Mengapa kualitas lembaga pendidikan menjadi bahan perbincangan yang menarik? Hal ini disebabkan karena pengaruh lembaga pendidikan yang berkualitas dapat dirasakan secara langsung dalam perkembangan serta kehidupan masyarakat, kehidupan kelompok, dan kehidupan individu. Jika bidang - bidang lain seperti ekonomi, pertanian, perindustrian berperan menciptakan sarana dan prasarana bagi kepentingan manusia, maka lembaga pendidikan berurusan langsung dengan pembenukan manusianya. Lembaga pendidikan menentukan model manusia yang akan di hasilkannya, yakni manusia yang berkualitas dan berkepribadian. Lembaga pendidikan menjadi sesuatu yang sangat penting dan berharga bagi kepentingan suatu bangsa, karena berpengaruh positif terhadap segala bidang kehidupan dan berhubungan langsung dengan kepribadian bangsa Indonesia. Hanya dengan lembaga pendidikan yang benar bangsa Indonesia akan terbebas dari krisis multidimensi yang berkepanjangan.
\end{abstract}

Kata kunci: Fungsi Manajemen, perencanaan, Pembelajaran

\footnotetext{
${ }^{1}$ Penulis adalah dosen tetap pada jurusan Tarbiyah STAIN Manado
} 


\section{A. Pendahuluan}

Sebuah sekolah adalah organisasi yang kompleks dan unik. Dikatakan kompleks karena di dalamnya terdapat beberapa elemen yang satu sama lain saling berpengaruh dan saling menentukan. Dikatakan unik karena di sekolah terdapat transfer of knowledge dan transfer of value yang tidak dijumpai pada organsasi lain selain sekolah sehingga memerlukan tingkat koordinasi yang tinggi. Oleh sebab itu kepala sekolah yang berhasil, yaitu tercapainya tujuan sekolah, dan tujuan dari setiap individu yang ada didalam lingkungan sekolah, harus memahami dan menguasai peranan organisasi dan hubungan kerjasama antar individu. Individu - individu disini adalah guru dan tenaga kelembaga keagamaan yang melakukan kegiatan dalam rangka mensukseskan proses pembelajaran sebagai bagian dari kegiatan lembaga keagamaan.

Kegiatan pembelajaran yang berlangsung di sekolah bersifat formal, disengaja, direncanakan, dengan bimbingan guru. Apa yang hendak dicapai dan dikuasai oleh peserta didik dituangkan dalam tujuan belajar, dipersiapkan bahan yang harus dipelajari, dipersiapkan juga metode pembelajaran yang bervariasi yang, dan melakukan evaluasi pembelajaran untuk mengetahui kemajuan belajar peserta didik. ${ }^{2}$

Kegiatan ini merupakan suatu bentuk perencanaan pembelajaran sebagai bagian integral dari proses pembelajaran yang mengacu pada kurikulum yang berlaku. Melalui perencanaan yang matang, proses embelajaran akan berlangsungefektif dan efisien sehingga guru terhindar dari ketidakpastian dalam menyampaikan bahan pembelajaran.

Konsep menejemen apabila diterjemahkan pada pembelajaran, dapat diartikan sebagai usaha $\mathrm{d}$ an tindakan kepala sekolah sebagai pemimpin intruksional di sekolah dan usaha maupuntindakan guru sebagai pemimpin pembelajaran di kelas yang dilaksanakan sedemikian rupa untuk memperoleh

2 Lihat Syaiful sagala, Konsep dan Makna Pembelajaran untuk Membantu Memecahkan Problematika Belajar dan Mengajar ( Cet. V; Bandung: Alfabeta,2007),h.135. 
hasil dalam rangka mencapai tujuan program sekolah dan juga tujuan pembelajaran. ${ }^{3}$ Artinya bahwa manajemen pembelajaran di sekolah merupakan pengelolaan pada unit pekerjaan oleh seorang guru yang diberi wewenang untuk pekerjaan itu yang bermuara pada suksesnya proses pembelajaran.

Mengacu pada pernyataan diatas, maka keefektifan pembelajaran dapat di capai apabila fungsi - fungsi manajemen, yakni fungsi perencanaan, pengorganisasian, penggerakan/ kepemimpinan, dan pengawasan dapat diaplikasikan dengan baik dan benar pada pembelajaran Lembaga Keagamaan agama Islam. Ini berarti bahwa guru PAI harus melakukan perubahan dalam orientasi pembelajaran pada keberhasilan proses pembelajaran, dengan menerapkan fungsi- fungsi manajemen.

Terhadap perubahan itu, Allah swt. Berfirman dalam Q.S. AL$\mathrm{Ra}$ 'du/13: 11

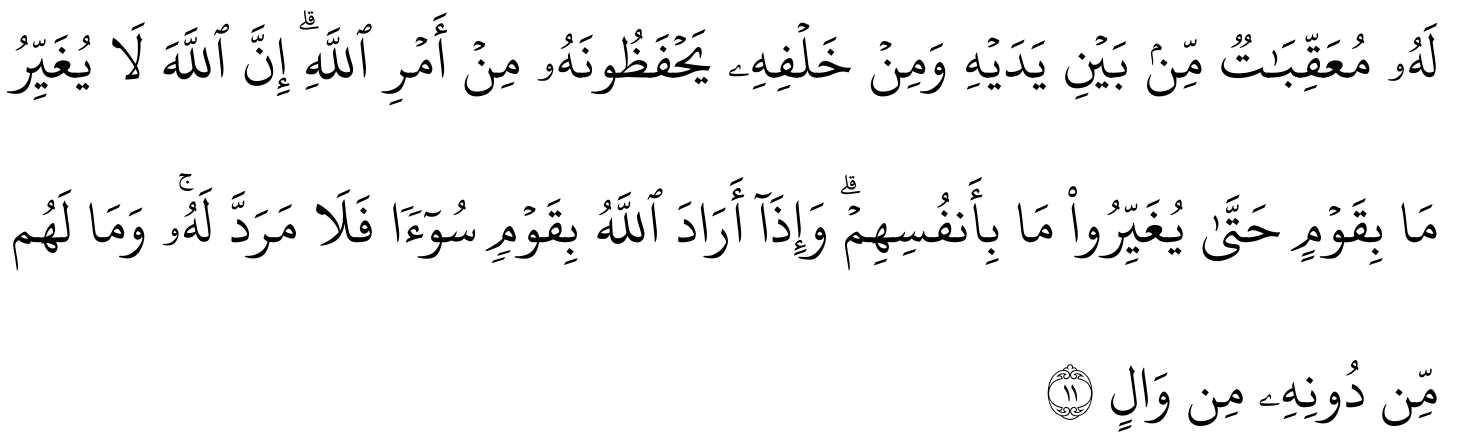

Terjemahnya:

Sesungguhnya Allah tidak mengubah keadaan suatu kaum sehingga mereka mengubah keadaan yang ada pada diri mereka sendiri. Dan apabila

\footnotetext{
${ }^{3}$ Lihat Ibid.,h.140
} 
Allah menghendaki keburukan terhadap suatu kaum, maka tak ada yang dapat menolaknya; dan sekali- kali tak ada pelindung bagi mereka selain Dia. ${ }^{4}$

Dari ayat diatas dapat dipahami bahwa yang bisa melakukan perubahan pada pembelajaran adalah guru itu sendiri. Guru melakukan perubahan terhadap pola pembelajaran dengan membuat perencanaan terlebih dahulu sebeum melakukan pembelajaran, karena ada sebagian guru yang berpandangan bahwa perencanaan pembelajaran tidak diperlukan lagi karena perencanaan pembelajaran hanyalah sebagai alat bagi supervisor/ penilk untuk mengecek pekerjaan guru saja. Disamping melakukan perencanaan, guru juga harus mampu mengorganisir, menggerakan dan melakukan penilaian pembelajaran.

Perencanaan yang baik dalam pembelajaran memainkan peranan yang penting bagi guru sebagai tugas profesionalnya, karena hal ini merupakan langkah awal sebelum pembelajaran berlangsung. Perencanaan juga membimbing guru untuk melaksanakan proses pembelajaran.

Kegiatan pengorganisasian bagi guru dalam pembelajaran dimaksudkan untuk menentukan siapa yang akan melaksanakan tugas sesuai dengan prinsip pengorganisasian, dengan membagi tanggung jawab setiap personil sekolah dengan jelas sesuai bidang, mata pelajaran, tanggung jawabnya. ${ }^{5}$ Pengorganisasian dalam pembelajaran berarti pembagian tugas sesuai dengan wewenangnya masing- masing. Kepala sekolah bertugas memberikan fasilitas dan kelengkapan untuk proses pembelajaran, guru sebagai pendidik bertugas mengkondisikan kelas, menata peserta didik, dan segala sesuatu yang berkaitan dengan suksesnya pembelajaran, termasuk mengolah kelas sebagai prasyarat manajemen pembelajaran. Guru harus

${ }^{4}$ Departemen Agama RI, AL-Qur'an dan Terjemahnya (Bandung:Jum'anatul' Ali Art,2005), h.253

${ }^{5}$ Lihat Syaiful sagala, op.cit.,h.143 
mampu mengupayakan suasana kelas yang kndusif sebelum pembelajaran dimulai sehingga pembelajaran bisa berjalan dengan baik.

Kegiatan penggerakan (actuating) atau disebut juga "gerakan aksi" mencakup kegiatan yang dilakukan seorang menejer untuk mengawali dan melanjutkan kegiatan yang ditetapkan oleh unsur perencanaan dan pengorganisasian agar tujuan dapat dicapai. Kegiatannya mencakup pemuasan kebutuhan manusiawi dan pegawai- pegawai, memberi penghargaan, memimpin, mengembangkan dan memberi kompensasi kepada pegawai atau pekerja. ${ }^{6}$ Fungsi penggerakan dalam pembelajaran berarti seorang guru harus mampu memberikan motivasi, arahan, dan bimbingan agar peserta didik dapat belajar dengan antusias, baik belajar di kelas maupun di luar kelas sehingga tunjuan pembelajaran dapat tercapai dengan optimal.

Fungsi pengawasan adalah fungsi manajemen yang terakhir dimana fungsi ini merupakan alat untuk mengukur dan menilai hasil rencana yang dicanangkan pada fungsi pertama, memberikan imbalan kepada staff sesuai kinerja yang ditunjukkan, dan merancang serta merencanakan kembali sambil memperbaiki hal- hal yang belum sempurna. ${ }^{7}$ Fungsi pengawasan dalam pembelajaran berarti kepala sekolah memberikan pengawasan dan penilaian terhadap pelaksanaan pembelajaran, apakah pembelajaran telah sesuai dengan tujuan yang diharapkan atau belum.

Pengawasan yang dilaksanakan oleh guru berarti guru memberikan penilaian terhadap pelaksanaan pembelajaran, apakah pembelajaran telah sesuai dengan tujuan yang telah di rencanakan atau belum. Jadi yang dinilai adalah proses pembelajaran dan hasil belajar.

Apabila fungsi- fungsi manajemen diaplikasikan dalam pembelajaran tentunya pembelajaran berlansung dengan tertib, terarah dan terencana dan

${ }^{6}$ Lihat George R. Terry, Guide to Management, terj. J. Smith DFM, Prinsip- Prinsip Manajemen (Jakarta: Bumi aksara,2000), h.17.

${ }^{7}$ Lihat Azhar Arsyad, pokok- pokok manajemen (Yogyakarta: Pustaka Pelajar,2003),h.20 
mencapai sasaran. Beberapa hal yang menjadi penghambat pembelajaranpun dapat di antisipasi dan diminimalisir sedini mungkin dan tujuan yang diharapkanpun akan terpenuhi dengan baik.

Berdasarkan uraian di atas maka permasalahan dalam tulisan ini adalah:

1. Pengertian manajemen

2. Fungsi- fungsi manajaemen

\section{B. Pembahasan}

\section{Pengertian manajemen}

Istilah manajemen dalam kehidupan sehari- hari menunjukan gejala semakin lama semakin akrab bagi segala aktivitas kehidupan manusia, meskipun awalnya lebih dominan dipergunakan dalam lingkungan organisasi bidang ekonomi. Dalam lingkup dunia organisasi yang bergerak dibidang perekonomian dan berbagi jenis usaha (perusahaan) lainnya yang bersifat profit, penggunaan istilah manajemen merupakan sebuah keniscayaan untuk dapat diaplikasikan pada sebuah organisasi secara efektif dan efisien, agar tujuan sebuah organisasi bisa tercapai dengan baik.

Dalam realitasnya, terdapat beberapa kesamaan dalam mengaplikasikan manajemen pada beberapa orhanisasi profit dan nonprofit, akan tetapi sulit untuk di bantah bahwa terdapat pula berbagai perbedaan prinsip pada kedua organisasi tersebut.

Manajemen berasal dari kata to manage yang berarti mengurus, mengatur, melaksanakan, mengelolah. ${ }^{8}$ Pengaturan ini dilakukan dengan tahap- tahap tertentu melalui proses yang teratur untuk mencapai tujuan yang diinginkan yang telah ditetapkan sebelumnya. Istilah manajemen (management) juga telah diartkan oleh berbagai kalangan dari berbagai

8 John M. Echols dan Hassan Shadily, An English- Indonesian Dictionary (Cet.XXVI; Jakarta: Gramedia Pustaka Utama,2005),h.372 
perspektif yang berbeda- beda. Ada yang mengartikan pengelolaan, pembinaan, pengurusan, ketatalaksanaan, kepemimpinan, ketatapengurusan, administrasi dan sebagainya. ${ }^{9}$ Pemahaman dan pemaknaan ini bisa terjadi karena pemikiran mereka dipengaruhi oleh beberapa hal; latar belakang profesi dan pendidikannya yang berbedabeda. Akan tetapi sebenarnya antara arti yang satu dengan arti yang lainnya mempunya perbedaan penafsiran.

Beberapa pakar manajemen berpendapat, sebagaimana yang dikutip oleh B. Siswanto:

a. John D. Millett, Management is the process of directing and facilitating the work of people organized in formal groups to achive a desired goal (Manajemen adalah suatu proses pengarahan dan pemberian fasilita kerja kepada orang yang di organisasikan dalam kelompok formal untuk mencapai tujuan).

b. James A.F. Stonner dan Charles Wankel, management is the process of planning, organizing, leading, and controlling the efforts of organizational resources to achive stated organizational goals ( Manajemen adalah proses, perencanaan, pengorganisasian, kepemimpinan, dan pengendalian upaya anggota organisasi dan penggunaan seluruh sumber daya organisasi lainnya demi terwujudnya tujuan organisasi).

c. Paul Hersey dan Kenneth H. Blanchard, Management is working with and through individuals and groups to accomplish organizational goals (Manajemen adalah suatu usaha yang dilakukan dengan dan bersama individu atau kelompok untuk mencapai tujuan). ${ }^{10}$

9 Lihat B. Siswanto, Pengantar Manajemen(Cet. IV; Jakarta: Bumi Aksara,2008),h.1.

${ }^{10}$ Lihat Ibid 
Dari pendapat pakar manajemen di atas dapat di analisis bahwa Millet lebih menekankan pada fungsi pengarahan dan pemberian fasilitas kerja. Pengarahan yang dimaksud adalah pengarahan tentang seluk beluk pekerjaan dari atasan kepada bawahan dengan tujuan supaya tercapai tujuan yang telah digariskan oleh manajemen perusahaannya. Sedangkan pemberian fasilitas bertujuan untuk memudahkan bawahan melakukan aktivitas pekerjaannya supaya bawahan dapat bekerja dengan nyaman, aman, dan kondusif.

AF. Stonner dan Charles Wankel lebih menekankan pada berfungsinya perencanaan, pengorganisasian, kepemimpinan dan pengendalian sebuah perusahaan yang di kelolanya, dimana keempat unsur yang dimaksud merupakan rangkaian aktivitas yang saling mendukung dan mengisi secara berurutan.

Paul Hersey dan Kenneth H. Blanchard lebih menekankan pada proses pelaksanaan pekerjaan yang dilakukan dengan dan oleh masing- masing individu maupun kelompoknya untuk mencapai tujuan organisasi bersama, berarti disini ada kerja sama yang saling menguntungkan.

Senada dengan Paul Hersey dan Kennet H.Blanchard, Nanang Fattah berpendapat bahawa manajemen diartiksn sebagai ilmu, kiat, dan profesi. ${ }^{11}$ Manajemen diartikan sebagai ilmu karena manajemen adalah suatu bidang pengetahuan yang secara sistematik berusaha memahami mengapa dan bagaimana orang melakukan kerja sama. Manajemen diartikan sebagai kiat karena manajemen mencapai sasaran melalui cara- cara dengan mengatur orang lain didalam menjalankan tgas dan tanggung jawabnya. Manajemen diartikan

11 Lihat Nanang Fattah, Landasan Manajemen Pendidikan (Cet. VIII; Bandung: Remaja Rosdakarya, 2006),h.1. 
sebagai profesi karena manajemen dilandasi oleh keahlian khusus untuk mencapai suatu prestasi manajer.

Dari beberapa pendapat pakar diatas, dapat diambil kesimpulan bahwa menejemen itu merupakan suatu bentuk kerja sama untuk mencapai tujuan bersama dengan tahapan- tahapan tertentu. Hal- hal yang pasti ada dalam menejemen adalah;

a. Manajemen ada tujuan yang akan dicapai bersama

b. Manajemen merupakan perpaduan antara ilmu dan seni

c. Manajemen merupakan proses yang sistematis, terkoordinasi, dan terintegrasi dalam memanfaatkan unsurunsur manajemen yang disingkat $6 \mathrm{M}$, yakni men, money, methods, materials, machines, and market

d. Manajemen dapat diterapkan dalam suatu kegiatan apabila ada dua orang atau lebih yang melakukan kerja sama dalam suatu organisasi.

e. Manajemen menerapkan pembagian tugas dan tanggung jawab untuk masing- masing kegiatan

f. Manajemen terdiri dari berbagai fungsi yang saling mendukung dan melengkapi

g. Manajemen merupakan alat untuk mencapai tujuan sebuah organisasi. $^{12}$

Dengan demikian, manajemen sebagai bentuk pengaturan kerja sama merupakan suatu aktivitas yang membutuhkan perangkat yang memadai dengan orientasi pada tujuan yang telah ditetapkan bersama oleh suatu organisasi.

Manajemen sebagai ilmu dan seni amatlah penting untuk mengatur dan mengendalikan kehidupan sebuah organisasi baik organisasi profit

12 Malayu. S.P. Hasibuan, Manajemen: Dasar, Pengertian, dan masalah (Cet. VI;Jakarta: Bumi Aksara,2007),h.3. 
maupun nonprofit. Penguasaan yang baik terhadap manajemen dan segala perangkatnya, memungkinkan sebuah organisasi berjalan dengan baik dan benar.

Mengenai pentingnya sebuah manajemen adalah karena keterbatasan manusia yang tidak bisa melaksanakan sebuah kegiatan organisasi secara perseorangan menjadikannya perlu ada pembagian tugas dan kewenangannya yang harus dilaksanakan oleh orang lain. Tugas- tugas dan tanggung jawab yang diserahkan kepada orang lain inilah yang akan memudahkan seseorang melaksanakan kegiatan dan terjalin adanya kerja sama yang baik, sehingga pekerjaan semakin mudah dan tidak terasa berat.

Pentingnya adanya manajemen pada sebuah organisai adalah:

a. Pekerjaan itu berat dan sulit dikerjakan sendiri, sehingga diperlukan pembagian tugas dan tanggung jawab dalam menyelesaikannya.

b. Pekerjaan itu berat dan sulit dikerjakan sendiri, sehingga diperlukan pembagian tugas perusahaan akan dapat berasil dengan baik jika manajemen diaplikasikan dengan baik pula.

c. Manajemen yang baik akan meningkatkan daya guna dan hasil guna semuah potensi yang dimiliki oleh perusahaan/organisasi.

d. Manajemen yang baik akan meminimalkan pemborosanpemborosan hal-hal yang tidak berguna

e. Manajemen menetapkan tujuan dan usaha untuk mewujudkannya dengan memanfaatkan unsur manusia, dana, cara-cara yang digunakan, bahan-bahan, peralatan, dan pasar.

f. Manajemen perlu untuk kemajuan dan pertumbuhan sebuah organisasi/ perusahaan

g. Manajemen mengakibatkan pencapaian tujuan secara teratur

h. Manajemen merupakan suatu pedoman pikiran dan tindakan 
i. Manajemen selalu dibutuhkan dalam setiap kerja sama sekelompok orang. ${ }^{13}$

Melihat keterangan diatas, dapat diambil kesimpulan bahwa manajemen sangat penting untuk mengatur sebuah kegiatan, baik kegiatan yang bersifat formal maupun nonformal. Kegiatan dalam rumah tangga, sekolah, perusahaan, organisasi, masyarakat, yayasan, pondok pesantren dan lain sebagainya demi terwujudnya kegiatan yang telah direncanakan sebelumnya. Karena manajemen merupakan aktivitas keja sama maka partisipasi anggota organisasi menjadi sangat penting. Sebuah organisasi/lembaga tidak akan berjalan dengan tertib dan lancar apabila masing- masing anggota tidak saling melakukan kerja sama yang baik.

\section{Fungsi- fungsi manajemen}

Malayu, S.P. Hasibuan berpendapat bahwa tujuan adanya pembagian fungsi manajemen adalah: pertama supaya sistematika urutan pembahasan suatu kegiatan organisasi lebih teratur, kedua, supaya analisis pembahasannya lebih mudah dan mendalam sehingga arahannya jelas dan lebih terinci, dan ketiga, supaya bisa menjadi pedoman pelaksanaan manajemen bagi manajer. ${ }^{14}$

Aneka ragam klasifikasi fungsi manajemen yang ada harus dipandang sebagai hal yang positif dalam arti dapat memperkaya pengetahuan dan pemahaman yang lebih mendalam tentang apa saja yang harus dilakukan oleh para manajer agar kemampuan organisasi mencapai tujuan dan berbagai sasarannya semakin meningkat. Merupakan kenyataan bahwa cara dan gaya seseorang ilmuan membuat klasifikasi fungsi- fungsi manajemen di pengarui oleh beberapa faktor, antara lain: filsafat hidup yang dianut, perkembangan pengetahuan yang telah dicapai,

\footnotetext{
${ }^{13}$ Ibid.,h.4

${ }^{14}$ Lihat Malayu, S.P. Hasibuan, op.cit.,h.37
} 
perkembangan teknologi dan pemanfaatannya, serta kondisi organisasi di mana fungsi itu di selenggarakan. ${ }^{15}$

Aneka ragam fungsi manajemen itu akan menambah khazanah bagi perkembangan ilmu manajemen sesuai dengan kondisi dan perkembangan ilmu pengetahuan dan teknologi.

Fungsi- fungsi manajemen dapat digolongkan menjadi dua jenis, yaitu fungsi organik dan fungsi penunjang. ${ }^{16}$ Fungsi organik adalah keseluruhan fungsi yang mutlak perlu dilakukan oleh para manajer dalam rangka pencapaian tujuan dan berbagai sasaran yang telah ditetapkan sebelumnya. Sedangkan fungsi penunjang adalah berbagai kegiatan yang di selenggarakan oleh satuan kerja dalam sebah organisasi yang dimaksudkan untuk mendukung semua fungsi- fungsi organik.

Adapun fungsi- fungsi manajemen yang dimaksud adalah:

a. Fungsi perencanaan (planning)

Perencanaan sebagai langkah awal sebelum melaksanakan fungsi- fungsi manajemen lainnya adalah menetapkan pekerjaan yang harus di laksanakan oleh sekelompok orang untuk mencapai tujuan yang digariskan oleh lembaga/ organisasi. ${ }^{17}$ Sedangkan Husaini Usman berpendapat, perencanaan adalah sejumlah kegiatan yang telah di tentukan sebelumnya untuk dilaksanakan pada suatu periode tertentu (masa yang akan datang) dalam rangka mencapai tujuan yang telah ditetapkan sebelumnya. ${ }^{18}$

Senada dengan Husain, Malayu S.P. Hasibuan berpendapat bahwa perencanaan adalah sejumlah keputusan mengenai keinginan 1998),h.43.

15 Lihat Sondang P.Siagian, Fungsi- fungsi manajerial (Jakarta: Bumi Aksara,

${ }^{16}$ Lihat Ibid.,h.44

${ }^{17}$ Lihat George R. Terry, Guide to Managenent, terj. J. Smith DFM., Prinsip-prinsip Manajemen (Cet VII; Jakarta: Bumi Aksara, 2003),h.17.

${ }^{18}$ Lihat Husaini Usman, Manajemen:Teori, Praktik, dan Riset Pendidikan (Cet.I; Jakarta: Bumi Aksara,2006),h.48 
dan berisi pedoman pelaksanaan untuk mencapai tujuan yang diinginkan itu. Dari setiap perencanaan mengandumg dua unsur, yaitu: tujuan dan pedoman. ${ }^{19}$ Sedangkan Azhar Arsyad berpendapat bahwa perencanaan adalah proses penyusunan dan penetapan tujuan dan bagaimana menempuhnya atau proses identifikasi kemana akan dan menujun dan bagaimana cara menempuh tujuan tersebut. ${ }^{20}$ Perencanaan merupakan tindakan yang akan dilakuakan pada masa yang akan datang berdasarkan pada asumsi.

Dari pendapat beberapa para ahli manajemen tersebut, dapat di pahami bahwa perencanaan merupakan proses awal untuk menyusun dan menetapkan tujuan organisasi yang akan dilaksanakan pada waktu yang akan dtang. Sehingga esensi perencanaan sebagai fungsi manajemen adalah pengambilan keputusan dengan memilih alternatif kegiatan yang akan atau tidak dilaksaakan agar usaha untuk menempuh tujuan organisasi berlangsung dengan efektif dan efisien

1) Asas perencanaan

Prinsip-prinsip perencanaan merupakan asumsi dasar yang harus dipertimbangkan pada setiap kegiatan perencanaan di buat supaya perencanaan bisa menjadi rencana yg akan dan dapat terlaksana dengan baik.

a. Principle of contribution to objective, setiap perencanaan dan segala perubahannya harus ditunjukan kepada pencapaian tujuan

b. Principle of ficiency of planning, suatu perencanaan efisien, jika perencanaan itu dalam pelaksanaannya dapat mencapai tujuan dengan biaya sekecil-kecilnya.

${ }^{19}$ Lihat Malayu S.P. Hasibuan, op.cit., h.93

${ }^{20}$ Lihat Azhar Arsyad, Pokok-pokok Manajemen (Cet, II; Yogyakarta: Pustaka Pelajar,2003), h.36 
c. Principle of primacy of planning,perencanaan adalah keperluan utama pemimpin dan fungsi-fungsi lainnya, organizing, staffing, directing, dan controlling.

d. Principle of pervasivennes of planning, akses pemerataan perencanaan memegang peran penting mengingat pemimpin pada tingkat tinggi banyak mengerjakan perencanaan dan bertanggung jawab atas berhasinya perencanaan itu

e. Principle of planning prenise, patokan-patokan perencanaan sangat berguna bagi ramalan, sebab premis-premis perencanaan dapat menunjukan kejadian-kejadian yang akan datang

f. Principle of policy flame work, kebijakan ini mewujudkan pola kerja, prosedur-prosedur kerja, dan program-program kerja tersusun

g. Principle of timing, adalah perencanaan waktu yang relatif singkat dan tepat

h. Principle of planning communication, perencanaan dapat disusun dan di koordinasikan dengan baik, jika setiap orang bertanggung jawab dengan baik, terhadap pekerjaaannya dan memperoleh penjelasan- penjelasan yang memadai mengenai bidang yang akan dilaksanakannya

i. Principle of alternative, alternatif ada pada setiap rangkaian kerja dan perencanaan meliputi pemilihan rangkaian alternatif dalam pelaksanaan pekerjaan, sehingga tercapai tujuan yang telah ditetapkan

j. Principle of limiting factor, dalam pemilihan alternatifalternatif pertama-tama harus ditujukan pada faktor-faktor strategis dan dapat membantu pemecahan masalah. Asas 
alternatif dan pembatasan faktor merupakan syarat mutlak dalam menetapkan keputusan

k. Principle of commitment, perencanaan harus mempertimbangkan jangka waktu keterikatan yang diperlukan untuk pelaksanaan pekerjaan

1. Principle of flexibility, perencanaan yang efektif memerlukan fleksibilitas, tetapi tidak berarti mengubah tujuan yang telah ditetapkan oleh manajemen pada waktu penetapan perencanaan

m. Principle of navigation change,perencanaan yang efektif memerlukan pengamatan yang terus menerus terhadap kejadian-kejadian yang timbul dalam pelaksanaannya untuk mempertahankan tujuan

n. Principle of strategic planning,perencanaan memerlukan tindakan seorang manajer memilih tindakan-tindakan yang diperlukan untuk menjamin pelaksanaan rencana agar tujuan tercapai dengan efektif. ${ }^{21}$

Perencanaan berdasarkan prinsip-prinsip yang telah disebutkan diatas merupakan fungsi utama manajer dalam melaksanakan menejemen yang tergantung pada baik buruknya sebuah rencana yang telah diruuskan sebelumnya. Perencanaan yang matang menjadi tolak ukur dalam menentukan kebijakan menejemen untuk melangkah lebih pasti.

2) Tujuan dan manfaat perencanaan

Adapun tujuan diadakan perencanaan adalah;

${ }^{21}$ Malayu, S.P. Hasibuan, op.cit.,h.93-94 
a. Standar pengawasan, yaitu dengan mencocokkan pelaksanaan dengan perencanaannya.

b. Mengetahui kapan pelaksanaan dan selesainya suatu kegiatan yang telah direncanakan

c. Mengetahui siapa saja yang terlibat (struktur organisasinya), baik kualifikasinya maupun kuantitasnya

d. Mendapatkan kegiatan yang sistematis termasuk biaya dan kualitas pekerjaan yang telah dipersiapkan sebelumnya.

e. Meminimalkan kegiatan-kegiatan yang tidak produktif dan menghemat biaya, tenaga, dan waktu

f. Memberikan gambaran yang menyeluruh mengenai kegiatan pekerjaan

g. Menyerasikan dan memadukan beberapa subkegiatan

h. Mendeteksi hambatan kesulitan yang bakal ditemui

i. Mengarahkan pada pencapaian tujuan. ${ }^{22}$

Malayu S.P. Hasibuan berpendapatbahwa tujuan dilaksanakan perencanaan adalah

a) Perencanaan bertujuan untuk menetukan tujuan, kebijakankebijakan, prosedur, dan program serta memberikan pedoman cara-cara pelaksanaanyang efektif dalam mencapai tujuan

b) Perencanaan bertujuan untuk menjadikan tindakan ekonomis, karena semua potensi yang dimiliki terarah dengan baik kepada tujuan

c) Perencanaan adalah satu usaha untuk memperkecil resiko yang dihadapi pada masa yang akan datang

d) Perencanaan menyebabkan kegiatan-kegiatan yang dilakukan secara teratur dan bertujuan

\footnotetext{
${ }^{22}$ Husaini Usman, op.cit. h.48
} 
e) Perencanaan memberikan gambaran yang jelas dan lengkap tentang seluruh pekerjaan

f) Perencanaan membantu penggunaan suatu alat pengukuran hasil kerja

g) Perencanaan menjadi suatu landasan untuk pengendalian

h) Perencanaan merupakan usaha untuk menghindari mismanagement dalam penempatan karyawan

i) Perencanaan membantu peningkatan daya guna dan hasil guna organisasi. ${ }^{23}$

Baik Husain maupun Malayu sepakat bahwa perencanaan bertujuan agar pelaksanaan suatu kegiatan organisasi berjalan dengan tertib sesuai dengan tujuan yang telah disepakati bersama, sehingga dapat meminimalkan gangguan-ganguan yang akan menghambat tercapainya tujuan.

Adapun manfaat dari perencanaan adalah

a. Standar pelaksanaan dan pengawasan

b. Pemilihan berbagai alternatif terbaik

c. Penyusunan skala prioritas, baik sasaran maupun kegiatan

d. Menghemat pemanfaatan sumber daya organisasi

e. Membantu menejer menyesuaikan diri dengan perubahan lingkungan

f. Alat memudahkan dalam berkoordinasi dengan pihak terkait dan

g. Alat meminimalkan pekerjaan yang tidak pasti. ${ }^{24}$

Manfaat perencanaan diatas bernilai besar bagi terselenggaranya kegiatan organisasi dengan menerapkan skala prioritas kegiatan yang lebih mendesak. Kegiatan yang dianggap belum mendesak tidak dilaksanakan dulu

\footnotetext{
${ }^{23}$ Malayu, S.P. Hasibuan, op.cit.,h. 95

${ }^{24}$ Husaini Usman, loc.cit
} 
3) Jenis-jenis perencanaan

Dalam setiap organisasi, baik organisasi profit maupun nonprofit, perencanaan disusun dalam suatu hierarki yang sejajar dengan struktur prganisasi. Stoner dan Wankel dalam B. Siswanto membagi perencanaan menjadi dua jenis, yaitu rencana strategis dan rencana operasional

a) Rencana strategis (strategic plan)

Perencanaan strategis adalah proses pemilihan tujuan organisasi, penentuan kebijakan dan program yang perlu untuk mencapai sasaran dan tujuan tertentu, serta menetapkan metode yang perlu untuk menjamin agar kebijakan dan program strategis iyu dilaksanakan. ${ }^{25}$ T.Hani Handoko berpendapat, perencanaan strategis adalah proses pemilihan tujuan-tujuan organisasi, penentuan strategi, kebijaksanaan dan programprogram strategis yang diperlukan untuk tujuan-tujuan tersebut; dan penetapan metode-metode yang diperlukan untuk menjamin bahwa strategis dan pelaksanaan telah diimplementasikan. ${ }^{26}$

Perencanaan strategi adalah proses perencanaan jangka panjang yang formal untuk menentukan dan mencapai tujuan organisasi. Rencana strategis dirancang untuk mencapai tujuan organisasi yang luas, yaitu umtuk melaksanakan misi yang merupakan satu-satunya alasan kehadiran organisasi.

b) Rencana operasional (operational plan)

Perencanaan operasional mempunnyai fokus yang lebih sempit, jangka waktu yang lebih pendek, dan melibatkan

25 Lihat B. Siswanto, Pengantar Manajemen, (Cet.IV; Jakarta: Bumi Aksara,2008), h.48

26 Lihat T. Hani Handoko, Manajemen (Cet XIII; Yogyakarta:PBFE Yogyakarta,1998),h.92 
manajemen tingkat bawah. ${ }^{27}$ Perencanaan operasional memusatkan perhatian apa yang akan dikerjakan pada tingkat pelaksanaan dilapangan. ${ }^{28}$ Perencanaan ini bersifat spesifik dan berfungsi memberi petunjuk konkrit tentang pelaksanaan suatu proyek atau program, baik tentang aturan, prosedur, dan ketentuan-ketentuan lain yang telah ditetapkan.

Perencanaan operasional tidak banyak membutuhkan pertimbangan-pertimbangan individual, sebab sebagian besar didasarkan pada data kuantitatif yang dapat diukur dan bersifat jangka pendek serta memberikan deskripsi rencana strategis.

Perencanaan strategis memberikan gambaran umum tentang bagaimana kegiatan dilaksanakan dalam jangka waktu yang panjang, sedangkan perencanaan operasional memberikan gambaran tentang bagaimana rencana strategis bisa dilaksanakan.

b. Fungsi pengorganisasian (organizing)

Setelah mennyusun rencana, selanjutnya diperlukan penyusunan/ pengelompokan kegiatan yang akan dilaksanakan dalam rangka usaha kerja sama. Perlunya pengorganisasian, pengelompokkan tanggung jawab, penyusunan tugas, tugas bagi setiap individu yang mempunyai tanggung jawab.

Pengorganisasian adalah pengelompokkan dan menentukan berbagai kegiatan penting dan memberikan kekuasaan untuk melaksanakan kegiatan-kegiatan tersebut. $^{29} \quad$ B.Siswanto mendefinisikan bahwa pengorganisasian adalah pembagian kerja

${ }^{27}$ Lihat Mamduh M, Hanafi, Manajemen Cet.I;Yogyakarta: AMP h. 21

${ }^{28}$ Lihat Harjanto, Perencanaan Pengajaran(Cet.I;Jakarta: Rineka Cipta, 1997),

29 Lihat A. Sihotang, manajemen Sumber Daya Manusia (Jakarta: Pradnya Paramita,2007),h.28 
yang direncanakan untuk diselesaikan untuk anggota kesatuan pekerjaan, penetapan hubungan antar pekerjaan yang efektif diantara mereka, dan pemberian lingkungan dan fasilitas pekerjaan yang wajar seingga mereka bekerja secara efisien. ${ }^{30}$

Ahmad Ibrahim berpendapat bahwa pengorganisasian adalah proses penetapan strktur peran, melalui penentuan aktivitasaktivitas yang dibutuhkan untuk mencapai tujuan-tujuan organisasi. Pengelompokan aktivitas-aktivitas, penugasan kelompok-kelompok aktivitas kepada manajer-manajer, pendelegasian wewenang untuk melaksanakannya, dan pengoordinasian hubungan wewenang. ${ }^{31}$

Pengorganisasian dalam organisasi berarti keseluruhan proses pembagian tugas dan tanggung jawab serta wewenang termasuk pengalokasian sumber daya dan dana kepada mereka yang berhak sesuai dengan tugas dan tanggung jawabnya masingmasing tanpa campur tangan manajer.

1) Proses pengorganisasian

Proses pengorganisasian dapat dilihat melalui bagan berikut ini. $^{32}$

\footnotetext{
${ }^{30}$ Lihat B.Siswanto, op.cit.,h.75

${ }^{31}$ Lihat Ahmad Ibrahim Abu Sinn, Al-Idarah fi Al-Islam, Terj. Dimyauddin Djuwaini, Manajemen Syariah: Sebuah Kajian Historis dan Kontemporer( Jakarta: Raja Grafindo

${ }^{32}$ Lihat Nanang Fattah, Landasan Manajemen Pendidikan Cet. VIII; Bandung:
} Persada,2006),h.91 Remaja Rosdakarya,2006),h.72 


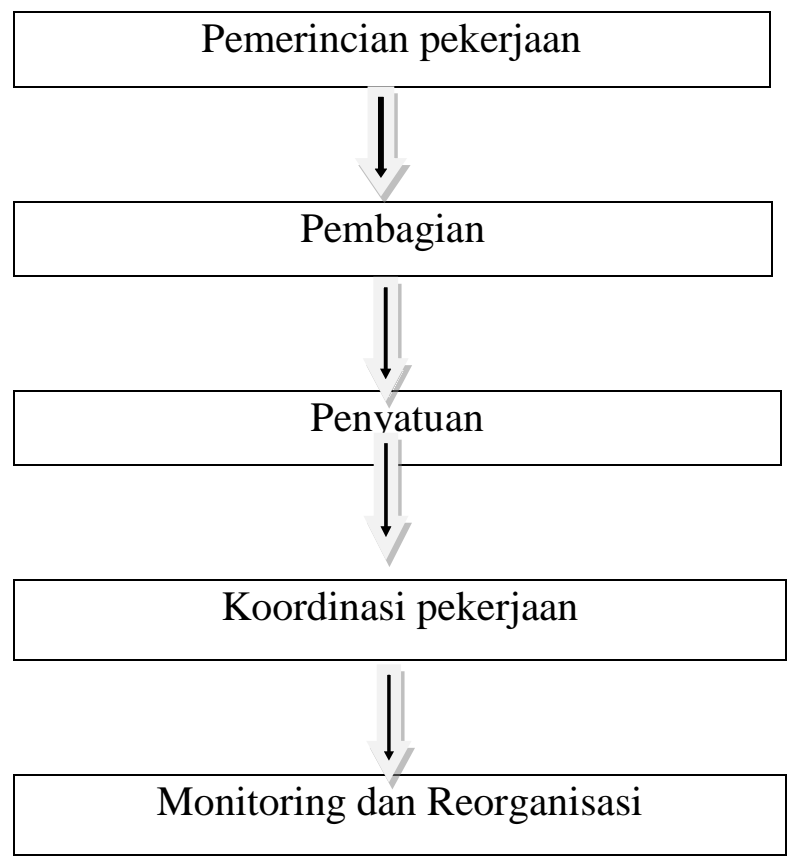

Dari bagan di atas, dapat dijelaskan bahwa pengorganisasian melaului tahap demi tahap secara berkesinambungan. Tahap pertama,yang harus dilakukan oleh manajer adalah merinci pekerjaan, yakni menentukan tugas-tugas apa yang harus dilakukan untuk mencapai tujuan organisasi. Tahap kedua, membagi seluruh pekerjaan menjadi kegiatan yang dapat dilaksanakan oleh perseorangan atau kelompok yang berdasarkan atas kualifikasi keahliannya. Tahap ketiga, menggabungkan pekerjaan para anggota dengan cara yang rasional dan efisien. Artinya pengelompokkan tugas didasarkan atas saling keterkaitan antara satu pekerjaan dengan pekerjaan yang lain. Tahap keempat, menetapkan mekanisme kerja untuk mengkoordinasikan pekerjaan dalam satu kesatuan yang 
harmonis, supaya tidak timbul konflik diantara anggota pekerja yang dimaksud. Tahap kelima,melakukan monitoring dan mengambil langkah-langkah penyesuaian untuk mempertahankan dan meningkatkan efektivitas organisasi.

2) Asas-asas pengorganisasian

Untuk terwujudnya organisasi yang efektif dan efisien perlu diterapkan asas-asas (prinsip-prinsip) organisasi sebagai berikut:

a) Principle of organizational (asas tujuan organisasi), adalah tujuan organisasi harus jelas dan rasional, apa bertujuan untuk mencari laba ataukah untuk memberi pelayanan.

b) Principle of unity of objective, (asas kesatuan tujuan), adalah harus ada kesatuan tujuan yang ingin dicapai

c) Principle of unity of command (asas kesatuan perintah), adalah bahwa setiap bawahan menerima perintah ataupun memberikan pertanggung jawaban hanya kepada satu orang atasan, tetapi satu orang atasan dapat memerintah beberapa orang bawahan

d) Principle of the span of management (asas rentang kendali), adalah seorang manajer hanya dapat memimpin secara efektif sejumlah bawahan tertentu, misalnya 3 sampai 9 orang. Jumlah bawahan tergantung kecakapan dan kemampuan manajer yang bersangkutan.

e) Principle of delegation of authority (asas pendelegasian wewenang), adalah pendelegasian wewenang dari seseorang atau kelompok orang kepada orang lain harus jelas dan efektif, sehingga ia mengetahui wewenangnya. 
f) Principle of parity of authority and responsibility (asas keseimbangan wewenang dan tanggung jawab), adalah wewenang dan tanggung jawab harus seimbang. Wewenang yang didelegasikan dengan tanggung jawab yang timbul karenanya harus sama besarnya.

g) Principle of responsibility (asas tanggung jawab), adalah hendaknya pertanggungjawaban dari bawahan terhadap atasan harus sesuai dengan wewenang dan pelimpahan wewenang.

h) Principle of departementation (principle of devision of work=asas pembagian kerja), adalah pengelompokan tugas-tugas, pekerjaan-pekerjaan, atau kegiatankegiatan yang sama kedalam satu unit kerja hendaknya didasarkan atas eratnya hubungan pekerjaan tersebut.

i) Principle of personal placement (asas penempatan personalia), adalah hendaknya penempatan orang-orang pada setiap jabatan harus didasarka atas kecakapan, keahlian, dan keterampilannya(the right man, in the right job).atau penempatan karyawan yang tepat sesuai dengan keahlian yang dimilikinya.

j) Principle of scalar chain (asas jenjang berangkai), adalah hendaknya saluran perintah atau wewenang dari atas kebawah harus merupakan mata rantai vertical yang jelas dan tidak terputus-putus serta menempuh jarak terpendek

k) Principle of efficiency (asas efisiensi) adalah suatu organisasi dalam mencapai tujuannya harus dapat mencapai hasil yang optimal dengan pengorbanan minimal 
1) Principle of continuity (asas kesinambungan), adalah organisasi harus mengusahakan cara-cara untuk menjamin kelangsungan hidupnya.

m) Principle of coordination (asas koordinasi), adalah mensingkronkan dan mengintegrasikan segala tindakan, supaya terarah kepada sasaran yang akan dicapai. ${ }^{33}$

Prinsip-prinsip di atas harus dipahami dan diaplikasikan pada pengorganisasian supaya tujuan organisasi baik profit maupun nonprofit terlaksana dengan baik dan mencapai sasaran yang dituju.

Dalam proses pengorganisasian ada 4 hal yang harus diperhatikan:

1) Pembagian kerja

2) Pengelompokan pekerjaan

3) Penentuan relasi antar bagian dalam organisasi.

4) Penentuan mekanisme untuk mengintegrasikan aktivitas antar bagian dalam organisasi atau koordinasi. ${ }^{34}$

Keempat hal di atas merupakan aktivitas pengorganisasian yang bisa menentukan keberhasilan organisasi dalam menjalankan fungsi pengorganisasian.

c. Fungsi pengarahan (directing)

Pada prinsipnya, tidak ada bawahan yang mampu bekerja sendiri tanpa bantuan orang lain sebagai atasannya. Bawahan selalu perlu mendapat bimbingan dan petunjuk dari atasan maupun sistem organisasinya supaya kegiatan yang dilakukan bisa diminimalisir tingkat kesalahannya.

\footnotetext{
${ }^{33}$ Malayu, S.P.Hasibuan,op.cit.,h.125-126

${ }^{34}$ Erni Tisnawati, op.cit.,h.11
} 
Pengarahan disebut juga gerakan aksi mencakup kegiatan yang dilakukan oleh seorang manajer untuk mengawali dan melanjutkan kegiatan yang ditetapkan unsur perencanaan dan pengorganisasian agar tujuan dapat tercapai. ${ }^{35}$ Kegiatannya meliputi penetapan dan pemuasan kebutuhan manusiawi dari para pegawai, memberi penghargaan, memimpin, mengembangkan dan memberi kompensasi kepada para pegawai.

B Siswanto berpendapat bahwa pengarahan adalah suatu proses bimbingan, pemberian petunjuk, dan instruksi kepada bawahan agar mereka dapat bekerja sesuai dengan rencana yang telah ditetapkan. ${ }^{36}$ Hadari Nawawi berpendapat bahwa kegiatan dalam actuating adalah melakukan pengarahan (commanding) bimbingan (directing), dan komunikasi (communication), termasuk koordinasi (coordination) dalam sebuah organisasi. ${ }^{37}$ Pengarahan dalam organisasi atau lembaga adalah kegiatan untuk menentukan bagi bawahan atau karyawan tentang apa yang harus dikerjakan atau tidak boleh dikerjakan, supaya tujuan organisasi yang telah ditetapkan dapat tercapai. Dengan pengarahan membuat semua orang dapat bekerja sama dan bekerja secara ikhlas dan bergairah untuk mencapai tujuan sesuai dengan perencanaan dan pengorganisasian.

Pengarahan dan bimbingan harus dilakukan secara terus menerus dengan menciptakan dan mengembangkan komunikasi terbuka secara efektif dan efisien, tanpa harus menyalahkan keada bawahan yang berbuat salah karena mereka memang

\footnotetext{
${ }^{35}$ Lihat George R. Terry. Op.cit.,h.17

${ }^{36}$ Lihat B. Siswanto, op.cit., h.111

${ }^{37}$ Lihat Hadari Nawawi,op.cit.,h.95
} 
membutuhkan bimbingan dan arahan untuk dapat bekerja dengan baik dan benar.

1) Tujuan pengarahan

Tujuan pengarahan secara umum yang akan dicapai pada sebuah organisasi adalah:

a) Menjamin kontinuitas perencanaan

Perencanaan ditetapkan untuk dijadikan pedoman normatif dalam pencapaian tujuan yang telah ditetapkan. Pelaksanaan kerja yang baik akan sesuai dengan rencana yang telah ditetapkan sebelumnya. Pengarahan dilakukan utuk menjamin kelangsungan perencanaan yang telah di tetapkan meskipun memiliki sifat fleksibel namun prinsip yang terkandung didalamnya harus tetap terjamin kontinuitasnya.

b) Membudayakan prosedur standar

Prosedur akan memberikan petunjuk detail untukmelaksanakan urutan-urutan tindakan yang sering atau biasa terjadi. Melalui pengarahan, prosedur kerja yang telah ditetapkan dapat dilaksanakan sebagaimana mestinya.

c) Mengh indari kemangkiran yang tidak berarti

Kemangkiran adalah kondisi ketika seseorang tidak berada di tempat kerjanya diluar penyebab yang jelas dan tanpa pemberitahuan terlebih dahulu. Karyawan yang tidak masuk kerja tanpa memberitahukan kepada pimpinannyadinamakan karyawan yang mangkir. Melalui pengarahan, karyawan atau bawahan yang ada terhindar dari kemangkiran yang tidak berarti. 
d) Membina disiplin kerja

Pengarahan diterapkan agar terbina disiplin kerja dilingkungan organisasi. Disiplin kerja menyangkut esensi dari keberadaannya sebagai karyawan. Dan karyawan harus mempertanyakan tugas rutinnya dan bagaimana melaksanakan tugas tersebut dengan sebaik-baiknya, karena disiplin kerja akan membawa dampak yang positif bagi organisasi. Dengan disiplin kerja yang terjaga, organisasi akan mampu menghasilkan produk yang berkualitas

e) Membina motivasi yang terarah

Pengarahan juga memiliki tujuan untuk membina motivasi kerja para karyawan yang terarah, sehingga karyawan dapat melaksanakan pekerjaan dengan baik dan benar sambil dibimbing dan diarahkan untuk menghindari kesalahan yang fatal bagi sebuah organisasi. ${ }^{38}$

Tujuan pengarahan di atas hendaknya dapat terlaksana dengan baik dengan memaksimalkan potensi sumber daya manusia yang dimiliki oleh sebuah organisasi tanpa mengesampingkan unsur manusiawinya.

A. Pokok-pokok masalah dalam pengarahan

Pokok-pokok masalah yang harus dipelajari dalam fungsi pengarahan adalah :

a) Tingkah laku manusia

Manajemen adalah usaha mencapai tujuan melalui kegiatan-kegiatan orang lain. Hal ini berarti manajer atau

${ }^{38}$ Lihat B. Siswanto, op.cit.,h.112-113 
pimpinan dalam sebuah perusahaan atau organisasi menyuruh bawahannya untuk mengerjakan sebagian dari tugas-tugasnya dalam mencapai tujuan organisasi. Pimpinan dalam membina kerja sama para bawahannya perlu memahami tingkah laku manusia.

Manusia dalam berkelompok mempunya latar belakang yang heterogen, seperti jenis kelamin, umur, pendidikan, agama, kebudayaan, kepentingan dan sebagainya. Ini yang harus dipahami pimpinan supaya bisa mengarahkan anggotanya dalam melaksanakan pekerjaannya dengan tulus ikhlas.

b) Hubungan manusiawi

Hubungan manusia adalah hubungan antar orang orang yang dilakukan dalam suatu organisasi. Ini berarti bukan hubunan dalam kekeluargaan, tetapi hubungan dalam sebuah organisasi untuk mewujudkan tujuan organisasi.

c) Komunikasi

Komunikasi merupakan hal yang sangat penting dalam manajemen, sebab proses manajemen bisa terlaksana bila dilakukan dengan komunikasi. Pemberian perintah, informasi, berita, saran dan menjalin hubungan hanya dapat dilakukan dengan komunikasi saja, tanpa komunikasi yang baik da terarah, proses manajemen tidak bisa terlaksana.

d) Kepemimpinan

Kepemimpinan yang baik, proses manajemen akan berjalan lancar dan karyawan akan bergairah melakukan pekerjaannya. Gairah kerja, produktivitas kerja, dan proses 
manajemen suatu organisasi akan baik, jika tipe, gaya, cara, atau style kepemimpinan yang diterapkan manajer baik. ${ }^{39}$

\section{d. Fungsi pengawasan (controlling)}

Pengawasan adalah fungsi terakhir dari proses manajemen yang sangat menentukan pelaksanaan fungsi-fungsi manajemen yang lain, karena peranan pengawasan sangat menentukan baik buruknya pelaksanaan suatu rencana yang telah ditetapkan sebelumnya.

Sondang P. Siagian berpendapat bahwa pengawasan adalah keseluruhan upaya pengamatan pelaksanaan kegiatan operasional guna menjamin bahwa berbagai kegiatan tersebut sesuai dengan rencana yang telah ditetapkan sebelumnya. ${ }^{40}$ Pengawasan merupakan fungsi manajemen yang bertujuan untuk memastikan bahwa aktivitas manajemen berjalan sesuai dengan tujuan yang direncanakan dengan penampilan sebaik mungkin dan untuk menyingkap kesalahan dan penyelewengan kemudian memberikan tindakan korektif. ${ }^{41}$

Senada dengan kedua pendapat diatas, A. Sihotang berpendapat bahwa pengawasan merupakan proses pengamatan dan pengaturan pelaksanaan sebuah kegiatan, apakah kegiatan telah berjalan sesuai dengan rencana yang telah ditentukan sebelumnya atau tidak. ${ }^{42}$

Dengan demikian pengawasan berarti satu tindakan untuk mengontrol aktivitas-aktivitas organisasi dan sekaligus sebagai

\footnotetext{
${ }^{39}$ Lihat Malayu, S.P. Hasibuan,op.cit.,h. 184-196

40 Lihat Sondang P. Siagian, Manajemen Stratejik Cet.V; Jakarta: Bumi

${ }^{41}$ Lihat Ahmad Ibrahim,op.cit., h.179

${ }^{42}$ Lihat A. Sihotang, op.cit.,h.8
} Aksara,2003),h.258 
koreksi terhadap rencana yang telah ditetapkan sebelumnya untuk mencegah terjadinya penyimpangan.

\section{Kesimpulan}

1. Bahwa manajemen sangat penting untuk mengatur semua kegiatan, baik kegiatan yang bersifat formal maupun nonformal. Kegiatan dalam rumah tangga, sekolah, perusahaan, organisasi, masyarakat, yayasan, pondok pesantren dan lain sebagainya demi terwujudnya kegiatan yang telah direncanakan sebelumnya. Karena manajemen merpakan aktivitas kerja sama maka partisipasi anggota organisasi menjadi sangat penting. Sebuah organisasi/lembaga tidak akan berjalan dengan terib dan lancar apabila masing-masing anggota tidak saling melakukan kerja sama yang baik.

2. Fungsi-fungsi manajemen adalah serangkaian kegiatan yang dijalankan dalam manajemen berdasarkan fungsinya masing-masing dan mengikuti suatu tahapan-tahapan tertentu dalam pelaksanaannya. Sebuah organisasi, apakah dia profit ataupun nonprofit, semuanya bertolak dari kemampuan manajer memahami fungsi-fungsi manajemen, sehingga mampu menjalankan kegiatan organisasi secara efektif dan efisien. Tanpa memahami fungsi-fungsi manajemen yang baik,seorang manajer tidak akan mampu membawa sebuah organisasi menjadi organisasi yang berhasil. 


\section{Daftar pustaka}

Abu Sinn,Ahmad Ibrahim. Al-Idarah fi Al-Islam. Terj.Dimyauddin Djuwaini, Manajemen Syariah: sebuah Kajian Historis dan Kontempore. Jakarta: Raja Grafindo Persada,2006.

Ahmadi, Abu dan Widodo Supriyono. Psikologi Belajar. Cet. 1; Jakarta:Rineka Cipta, 1991.

Arsyad, Azhar. Pokok-pokok Manajemen. Yogyakarta: Pustaka Pelajar,2003

Departemen Pendidikan Nasional. Kamus Besar Bahasa Indonesia.Edisi III. Jakarta: Balai Pustaka, 2003.

Departemen Agama RI. Metodologi Pendidikan Agama Islam. Edisi II, Jakarta: Dirjend. Bagais Direktorat Pekapontren,2002.

Pedoman Pendidikan Agama Islam di Sekolah Umum, Jakarta: Direktorat Jenderal Kelembagaan Agama Islam, 2004.

Al-Qur'an dan Terjemahnya. Bandung: Jum'anatul ‘Ali Art, 2005

Echols, John M. Dan Hassan Shadily. An English-Indonesian Dictionary. Cet XXVI; Jakarta: Gramedia Pustaka Utama 2005

Fattah, Nanang. Landasan Manajemen Pendidikan , Cet VIII; Bandung: Remaja Rosdakarya, 2006

Hamalik, Oemar. Proses Belajar Mengajar, Cet. VI; Jakarta: Bumi Aksara,2007. Kurikulum dan Pembelajaran. Cet VII; Jakarta: Bumi Aksara, 2008.

Harjanto. Perencanaan Pengajaran. Cet. I; Jakarta: Rineka Cipta, 1997 
Hasibuan Malayu S.P. Manajemen Dasar, pengertian, dan masalah.Cet. VI; Jakarta: Bumi Aksara,2007.

Husba, Mustafa. Administrasi Pendidikan: Aplikasi Fungsi-fungsi Manajemen pada Lembaga Pendidikan Formal . Cet, I; Makassar Pustaka Refleksi, 2005

Majid, Abdul. Perencanaan Pembelajaran: Mengembangkan Standar Kompetensi Guru,Cet IV. Bandung: Remaja Rosdakarya 2008

Muchith, M. Saekhan . Pembelajaran Kontekstual.Cet, I; Semarang: RaSAIL Media Group,2008

Muhaimin. Paradigma Pendidikan Islam: Upaya Mengaktifkan Pendidikan Agama di Sekolah. Cet I; Bandung: Remaja Rosdakarya,2001

Mulyasa E. Menjadi Guru Profesional: Menciptakan pembelajaran Kreatif dan Menyenangkan. Cet, VII; Bandung: Remaja Rosdakarya, 2008. - Standar Kompetensi dan Sertifikasi Guru. Cet III; Bandung: Remaja Rosdakarya, 2008.

Narbuko, Cholid dan Abu Ahmadi. Metodologi penelitian. Cet. VIII; Jakarta: Bumi Aksara,2007

Nasution, S. Kurikulum dan Pengajaran. Jakarta: Bina Aksara, 1989 . Metode Research (Penelitian Ilmiah). Cet, IX; Jakarta: Bumu Aksara, 2007

Republik Indonesia, Undang-undang R.I. Nomor:20 tahun 2003 tentang Sistem Pendidikan Nasional. Cet,I; Jakarta: Mini Jaya Abadi,2003 Peraturan Pemerintah R.I.nomor 19 Tahun 2005 tentang Standar Nasional Pendidikan. Cet, I; Jakarta: Mini Jaya Abadi 2006 
Rohiat . Manajemen Sekolah: Teori Dasar dan Praktik Dilengkapi dengan Contoh Rencana Strategis dan Rencana Operasional. Cet, I; Bandung: Refika Aditama,2008. Sagala, Syaiful. Konsep dan Makna Pembelajaran untuk Membantu Memecahkan Problematika Belajar dan Mengajar. Cet, V; Bandung: Alfabeta, 2007. .Administrasi Pendidikan Kontemporer. Cet, IV; Bandung: Alfabeta, 2008.

Sanjaya, Wina. Strategi Pembelajaran Berorientasi Standar Proses Pendidikan. Cet, IV; Jakarta: Kencana Prenada Media Group, 2008.

Siagian, Sondang P. Fungsi-fungsi Manejerial. Jakata: Bumi Aksara, 1998 . Manajemen Stratejik.Cet, V; Jakarta: Bumi Aksara, 2003

Sihotang, A. Manajemen Sumber Daya Manusia. Jakarta: Pradnya Paramita, 2007

Siswanto, B. Pengantar Manajemen. Cet, IV; Jakarta: Bumi Aksara,2008

Strauss, Anselm dan Juliet Corbin. Basic of Qualitative Research: Grounded TheoryProcedures and Techniques, Terj. Muhammad Shodiq dan Imam Muttqien, Dasar-dasar Penelitian Kualitatif: Tatalangkah dan Tekhnik-tekhnik Teoritasi Data.Cet, II; Yogyakarta: Pustaka Pelajar,2007

Sudjanah, Nana. Dasar-dasar Proses Belajar Mengajar, Cet,V; Jakarta: Sinar Baru Terry, George R. Guide to Management. Terj.J.Smith DFM, Prinsip-prinsip Manajement. Jakarta: Bumi Aksara,2000

Tohirin .Psikologi Pembelajaran Pendidikan Agama Islam. Jakarta: Raja Grafindo persada, 2005

Trisnawati, Ernie dan Kurniawan Saefullah. Pengantar Manajemen. Jakarta: Kencana, 2005 
Usman, Husaini. Manajemen: Teori, Praktik, dan Riset Pendidikan, Cet, I; Jakarta: Bumi Aksara, 2006

Wahjosumidjo. Kepemimpinan Kepala Sekolah. Jakarta: Raja Grafindo Persada,2005. 